\title{
Perkembangan Kognitif Bidang Auditori pada Anak Usia Dini
}

\author{
Yesi Novitasari ${ }^{\circledR}{ }^{\bowtie}$ Mohammad Fauziddin $^{2}$ \\ Email yesinovitasari@unilak.ac.id \\ Pendidikan Guru Pendidikan Anak Usia Dini, Universitas Lancang Kuning \\ Pendidikan Guru Pendidikan Anak Usia Dini, Universitas Pahlawan Tuanku Tambusai \\ DOI: $\underline{10.31004 / \text { obsesi.v5i1.640 }}$
}

\begin{abstract}
Abstrak
Perkembangan setiap anak usia dini sangat bervariasi dan tidak bersifat statis, hal ini berlaku pada semua aspek perkembangan anak termasuk perkembangan kognitif bidang auditori. Penelitian ini bertujuan untuk menganalisis perkembangan kognitif secara khusus dalam bidang auditori pada anak usia 4-5 tahun. Penelitian ini merupakan penelitian deskriptif dengan menggunakan pendekatan kuantitatif. Sampel penelitian ini adalah anak usia 4-5 tahun yang berjulah 20 anak di Taman kanak-Kanak Islam Terpadu Taruna Islam Pekanbaru. Hasil analisis data penelitian menunjukkan bahwa kemampuan mendengarkan bunyi/suara anak ada pada persentase $73 \%$, sedangkan kemampuan anak menirukan nada, birama dan warna suara berjumlah $41 \%$, selanjutnya dalam mengingat bunyi/suara kemampuan anak berjumlah 53\%, dan kemampuan mengulangi kembali bunyi/suara yang telah didengar berjumlah $43 \%$. Dengan demikian kemampuan kognitif bidang audiori anak usia 4-5 tahun di Taman kanak-Kanak Islam Terpadu Taruna Islam Pekanbaru dapat dirataratakan yakni 52,50\% dengan kategori cukup baik.
\end{abstract}

Kata Kunci: perkembangan kognitif; auditori; pendidikan anak usia dini

\begin{abstract}
The development of every early childhood is very varied and not static, this applies to every aspect of child development including cognitive development in the auditory field.This research aims to analyze cognitive development specifically in the auditory field in children aged 4-5 years. This research is a descriptive study using a quantitative approach. The sample of this research is children aged 4-5 years at Taman kanak-Kanak Islam Terpadu Taruna Islam Pekanbaru. The results of the analysis of the research data showed that the ability to listen to the sound of children is at a percentage of $73 \%$, while the ability of children to imitate the tone, bar and color of sound is $41 \%$, then in remembering the sound ability of children amounted to $53 \%$, and the ability to repeat the sounds that have been heard amounted to $43 \%$. Thus the cognitive abilities of the audiences in children aged 4-5 years at Taman kanak-Kanak Islam Terpadu Taruna Islam Pekanbaru can be averaged at $52.50 \%$ with a fairly good category.
\end{abstract}

Keyword: cognitive development; auditory; early childhood education

Copyright (c) 2020 Yesi Novitasari, Mohammad Fauziddin

$\square$ Corresponding author:

Email Address : yesinovitasari@unilak.ac.id (Pekanbaru, Riau, Indonesia)

Received 31 May 2020, Accepted 4 August 2020, Published 25 August 2020 


\section{PENDAHULUAN}

Pendidikan anak usia dini merupakan pendidikan formal sebelum anak memasuki sekolah dasar. Usia ini penting karena bagi anak usia ini merupakan usia emas (golden age) dimana didalamnya terdapat masa peka yang hanya datang sekali pada anak. Golden age merupakan waktu paling tepat untuk memberikan bekal yang kuat kepada anak. Urgensi pendidikan anak usia dini terletak pada pertumbuhan dan perkembangan anak. Anak memiliki dorongan yang kuat untuk mengenal lingkungan alam sekitar dan lingkungan sosialnya, selain itu anak juga ingin memahami segala sesuatu yang dilihat dan didengar. Untuk menciptakan generasi yang berkualitas, pendidikan harus dilakukan sejak usia dini dalam hal ini melalui Pendidikan Anak Usia Dini (Nasional, 2007). Seperti yang diketahui bahwa anak usia 0-8 tahun adalah masa golden age atau masa keemasan (Nasution et al., 2019), sehingga anak usia dini sangat membutuhkan stimulasi ramah yang disesuaikan dengan tahapan perkembagannya serta menyelaraskan dengan karakteristik masing-masing anak.

Qudsyi (2010) menjelaskan penting untuk dipahami bahwa proses pembelajaran yang dilakukan dalam PAUD haruslah mengacu pada karakteristik perkembangan anak usia dini dan segala sifat alami yang melekat pada diri anak. Disarming itu pemenuhan gizi juga harus diperhatikan untuk memaksimalkan pertumbuhan dan perkembangannya (Inten et al., 2019).

Perkembangan merupakan suatu proses perubahan serta peningkatan kemampuan manusia. Proses integrasi dari banyak struktur dan fungsi yang kompleks, saling berpengaruh satu sama lainnya (Syarifin, 2017). Perkembangan anak dapat dilihat dari perubahan-perubahan dimasa tumbuhnya hingga sampai pada tahap dewasa. Dimana perkembangan anak sangat erat kaitannya dengan lingkungan. Lingkungan yang dimaksudkan mencakup tiga hal yakni lingkungan keluarga, lingkungan sekolah, dan ligkungan masyarakat. Pemberian stumulasi aspek perkembangan kognitif merupakan tugas dari pendidik di Lembaga PAUD (Fauziddin \& Mufarizuddin, 2018). Keunikan pada perbedaan tumbuh dan kembangnya anak usia dini dipengaruhi beberapa faktor yaitu faktor penghambat dan faktor pengembang. Dalam (Peraturan Menteri Pendidikan Dan Kebudayaan Republik Indonesia Nomor 137 Tahun 2014 Tentang Standar Nasional Pendidikan Anak Usia Dini, 2014) dijelaskan bahwa lingkup perkembangan sesuai tingkat usia anak meliputi aspek nilai agama dan moral, fisik motorik, kognitif, bahasa, sosial emosional, dan seni. Aspek perkembangan kognitif pada anak usia dini telah ditetapkan indikatornya pada Standar Tingkat Pencapaian Perkembangan Anak (STPPA) yang dimuat dalam Permendikbud Nomor 137 tahun 2014 sesuai dengan tingkat usia anak.

Salah satu kemampuan yang dikembangkan pada PAUD adalah kognitif. Kemampuan kognitif ialah kemampuan anak untuk berfikir lebih kompleks serta melakukan penalaran dan pemecahan masalah, berkembangnya kemampuan kognitif ini akan mempermudah anak menguasai pengetahuan umum yang lebih luas, sehingga ia dapat berfungsi secara wajar dalam kehidupan masyarakat sehari-hari (Novitasari, 2018). Pada aspek pengembangan kognitif, kompetensi dan hasil belajar yang diharapkan pada anak adalah anak mampu dan memiliki kemampuan berfikir secara logis, berfikir kritis, dapat memberi alasan, mampu memecahkan masalah dan menemukan hubungan sebab akibat dalam memecahkan masalah yang dihadapi (Yamin \& Jamilah, 2010). Perkembangan kognitif meliputi tujuh bidang pengembangan yaitu auditori, visual, taktil, kinestetik, aritmatia, geometri, dan sains permulaan. Perkembangan auditori merupakan salah satu bentuk kemampuan dalam perkembangan kognitif dimana kemampuan auditori sangat erat kaitannya dengan bunyi dan indera pendengaran anak. Kemampuan kognitif bentuk auditori lebih dominan dalam menggunakan indera pendengaran untuk melakukan aktivitas belajar. Dengan kata lain, seseorang anak akan mudah menangkap stimulus atau rangsangan melalui alat indera pendengaran (telinga). Kemampuan auditorial memiliki kekuatan pada kemampuannya untuk mendengar (Sukadi, 2008). 
Kemampuan kognitif bentuk auditori merupakan kemampuan anak berbentuk pengetahuan dari hasil pengamatan dan pendengaran sebagai factor utama dalam memahami suatu hal pengetahuan melalui telinga dan kemudian mampu menyebutkan kembali dari hasil pendengaran tersebut. Selanjutnya (Khadijah, 2016) menyatakan bahwa pengembangan auditory anak usia dini merupakan pengembangan kemampuan anak usia dini dalam mendengar yang melalui proses menerima kumpulan bunyi benda, kosa kata atau kalimat yang memiliki makna dalam topik tertentu. Kemampuan mendengar anak usia dini merupakan kemahiran pokok dalam proses mempelajari suatu ilmu pengetahuan. Tujuan pengembangan auditori anak usia dini adalah memperoleh informasi dan dapat berinteraksi dengan lingkungan secara maksimal. Adapun upaya untuk meningkatkan keterampilan mendengarkan pada anak bisa dilakukan dengan cara kegiatan mendengarkan bercerita, mendengarkan suara-suara binatang, menebak suara, menyimak cerita, pesan berantai, menirukan suara, menirukan kalimat, menjawab pertanyaan, mendengarkan radio, mendengarkan kaset cerita untuk anak, lagu-lagu anak, dan lain sebagainya (Rusniah, 2017).

Dengan perkembangan auditori yang baik akan berpengaruh pada pengetahuan anak, kemampuan anak, serta pengalaman anak. Perkembangan auditori sangat berpusat pada alat pendengar. Oleh sebab itu ciri-cirinya yakni perhatiannya mudah terpecah, berbicara dengan pola berirama dan belajar dengan cara mendengarkan (Sumantri, 2015). Menurut (Aqib, 2011) kemampuan auditori memiliki ciri-ciri yaitu mengutamakan pendengaran, merekam lebih efektif, membaca dengan bersuara, dan menulis dnegan menghafal dan bersuara. Maka dalam hal ini kemampuan kognitif auditori merupakan kemampuan memahami dari hasil kegiatan melihat dan mendengar dari apa yang menjadi ucapan yang tersimpan di telinga (Yuliani, 2006). Selain itu menurut (Sukadi, 2008) menyatakan indikator kegiatan auditori adalah: a) saat bekerja sering berbicara sendiri, b) mudah terganggu oleh keributan atau hiruk pikuk disekitarnya, c) sering menggerakan bibir dan mengucapkan tulisan di buku, d) senang membaca dengan keras dan mendengarkan, e) dapat mengulangi kembali dan menirukan nada, birama dan warna suara dengan mudah, $\mathrm{f}$ ) merasa kesulitan menulis tetapi mudah dalam bercerita, g) lebih suka musik, h) lebih mudah belajar dengan mendengarkan dan mengingat apa yang di diskusika, dan i) suka berbicara, berdiskusi dan menjelaskan.

Dari sembilan indikator tersebut, peneliti hanya mengambil empat indokator. Alasan pemilihan empat indikator yang dipilih merupakan yang paling berkaitan dengan penelitian ini yaitu pengembangan auditori. Kemampuan auditori bukan saja anak dapat mendengar, namun juga dapat menirukan, mengingat, serta mengulang kembali bunyi/suara yang telah didengar. Berdasarkan observasi di lapangan fenomena yang terjadi yaitu jarang sekali guru atau pendidik yang melakukan kegiatan yang benar-benar berorientasi pada kognitif bidang auditori. Hasil observasi awal didapati guru hanya fokus kepada enam bidang perkembangan anak usia dini secara garis besar. Sehingga guru tidak mengetahui dengan jelas bagaimana perkembangan auditori tiap-tiap anak. Guru mengetahui urgensi auditori bagi anak namun guru belum memberikan stimulasi yang difokuskan pada pengembangan auditori anak usia dini. Oleh karena itu peneliti berupaya untuk menganalisis dan mendapatkan data real sehingga dapat dilakukan tindak lanjut yang cepat dan tepat kepada anak yang belum berkembang dengan baik. Mengigat kemampuan auditori sangat penting sekali untuk dilatih sejak usia dini agar dapat merangsang pikiran, perasaan, atensi serta motivasi anak dalam belajar sehingga anak dapat bertumbuh dan berkembang optimal dimasa emasnya hingga masa mendatang.

Berdasarkan fenomena diatas permasalahan yang akan diteliti adalah kondisi perkembangan kognitif bidang auditori anak usia 4-5 tahun di Taman kanak-Kanak Islam Terpadu Taruna Islam Pekanbaru pada indikator mendengarkan bunyi/ suara, menirukan nada, birama dan warna suara, mengingat bunyi/suara yang telah di dengar, dan mengulangi kembali bunyi/suara yang telah di dengar. 


\section{METODOLOGI}

Penelitian ini merupakan penelitian deskriptif dengan menggunakan pendekatan kuantitatif. Populasi penelitian ini mencakup seluruh anak usia 4-5 tahun di Taman kanakKanak Islam Terpadu Taruna Islam Pekanbaru yang berjumlah 41 anak. Sampel penelitian ini adalah anak kelompok A1 yang diambil dengan teknik purposive sampling. Adapun jumlah sampel pada penelitian ini yaitu 20 anak. Penelitian ini dilakukan pada bulan Januari - Maret 2020 di Taman kanak-Kanak Islam Terpadu Taruna Islam Pekanbaru. Populasi dan sampel pada penelitian ini dapat dilihat pada gambar berikut:

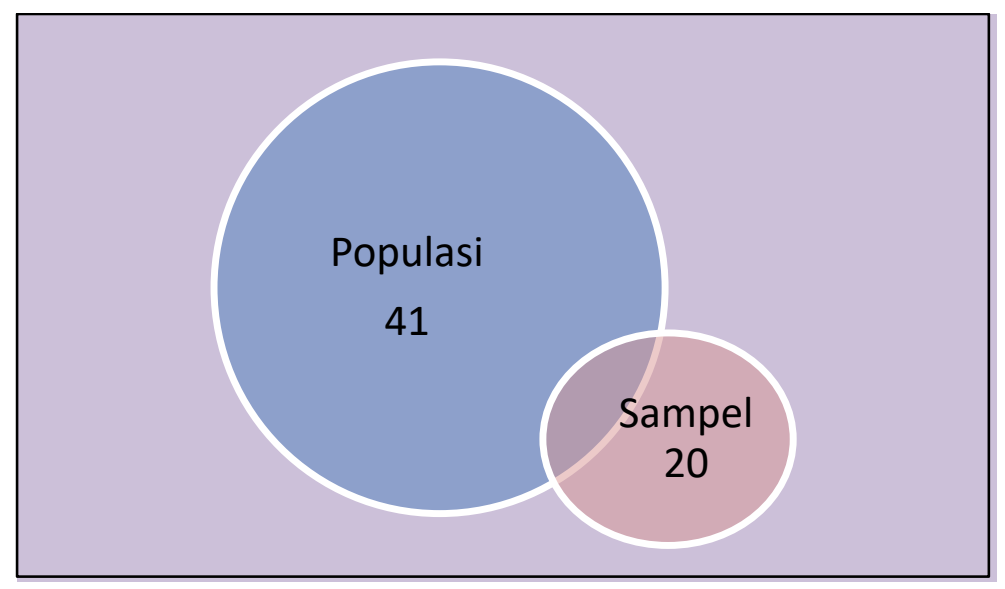

Gambar. 1 Populasi dan sampel penelitian

Pengumpulan data dilakukan secara kolaborasi dengan guru kelompok A1 di Taman kanak-Kanak Islam Terpadu Taruna Islam Pekanbaru. Peneliti melakukan observasi menggunakan instrumen penelitian yakni lembar observasi yang terdiri dari empat indikator. Setelah data diolah maka peneliti menetapkan kriteria penilaian masing-masing yang mengacu pada batasan pengelompokkan kriteria pengolahan data.

\section{HASIL DAN PEMBAHASAN}

Berdasarkan pengolahan data yang telah dilakukan, maka dianalisis berdasarkan pertanyaan penelitian yang telah diajukan. Adapun hasil penelitian dapat dilihat pada diagram berikut:

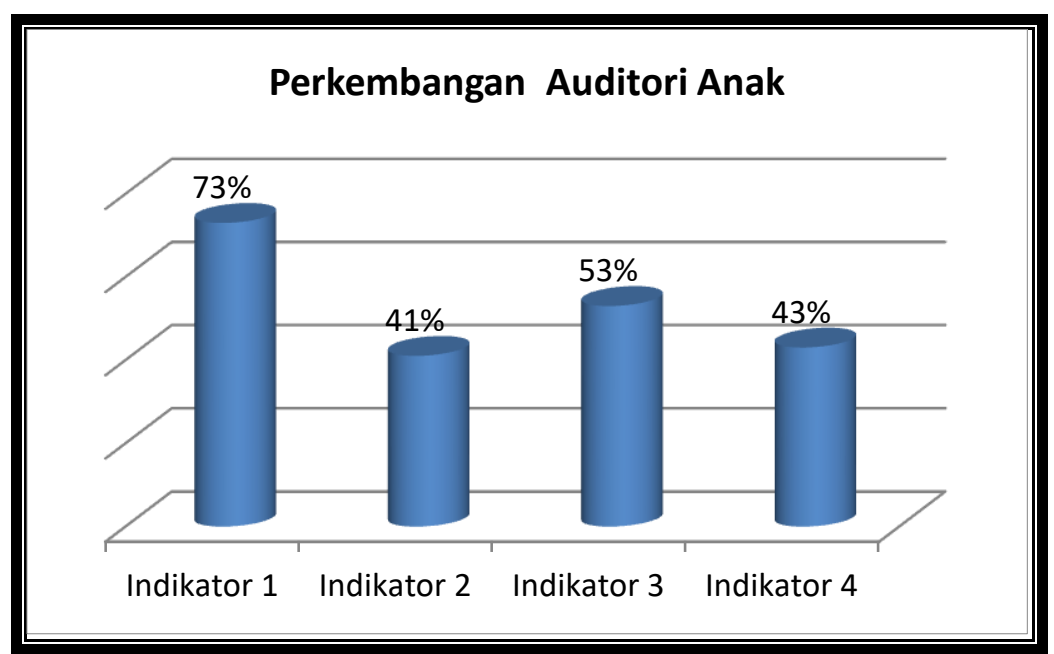

Diagram. 1 Perkembangan Auditori Anak 
Data penelitian perkembangan kognitif bidang auditori anak usia 4-5 tahun jika dirata-ratakan berjumlah 52,50\%, dengan kategori cukup baik. Sebagaimana hasil perhitungan pada masing-masing indikator dapat dilihat pada diagram diatas. Indikator 1 mengukur kemampuan anak dalam mendengar bunyi/suara memperoleh persentase paling tinggi diantara indikator lainnya yaitu 73\%, Indikator II yang mengukur kemampuan anak dalam menirukan nada, birama dan warna suara bernilai $41 \%$, selanjutnya Indikator III yang mengukur kemampuan anak dalam mengingat bunyi/suara berjumlah $53 \%$, dan diikuti $43 \%$ pada Indikator IV yang mengukur kemampuan anak dalam mengulangi kembali bunyi/suara yang telah didengar.

Adapun pembahasan perkembangan kognitif bidang auditori pada setiap indikator, sebagai berikut:

\section{Mendengarkan bunyi/suara}

Dari hasil pengolahan data hasil penelitian, didapatkan data pada indikator 1 yakni mendengarkan bunyi/suara sebagai berikut.

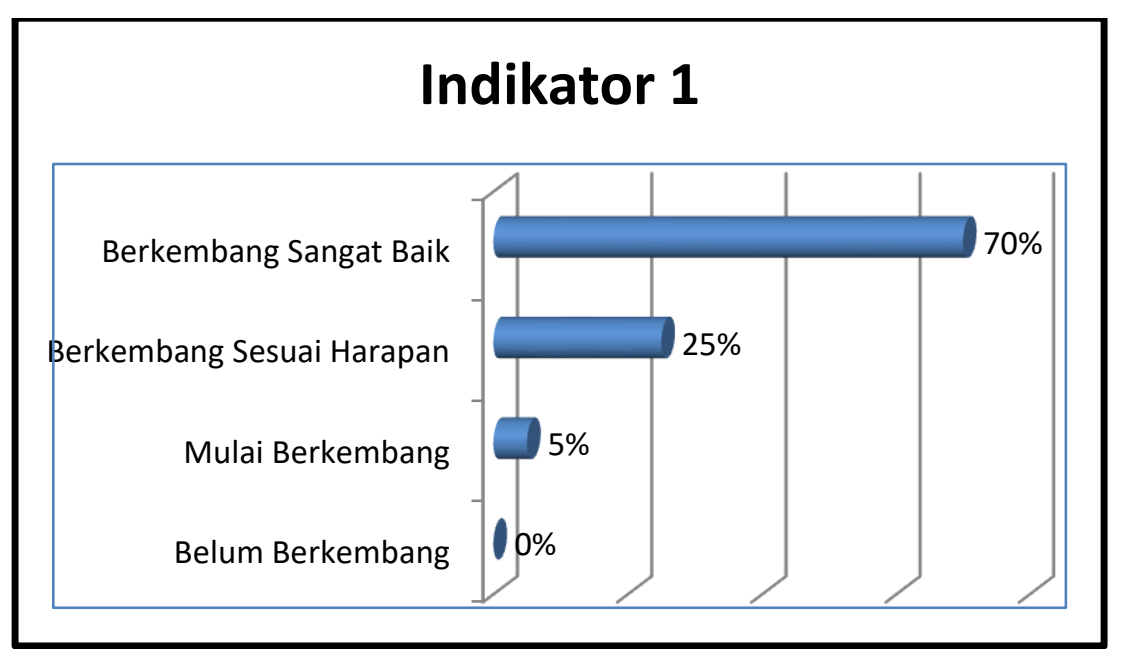

Diagram. 2 Data Indikator Pertama

Sebagaimana yang terlihat pada diagram diatas, bahwa $70 \%$ anak berkembang sangat baik dan $25 \%$ anak berkembang sesuai harapan dalam mendengarkan bunyi/suara. Namun demikian masih ada 5\% anak yang mulai berkembang. Mendengar merupakan salah satu keterampilan dasar dalam aspek perkembangan bahasa. Meskipun tanpa diajarkan setiap manusia bisa mendengar dengan mudah, namun tidak cukup sampai mendengar saja, manusia juga harus mampu mengolah informasi yang didengar. Karenanya penting sekali memberikan aktivitas yang merangsang kemampuan auditori, khususnya pada anak usia dini. Menurut Darna (2018) keterampilan mendengarkan perlu diajarkan dan dilatihkan dengan baik dan kontiniu mengingat pentingnya peran dalam kehidupan, baik di sekolah maupun di lingkungan masyarakat. Indera pendengaran anak sudah aktif bahkan sejak 0 tahun, sehingga tidak heran jika kemampuan anak dalam mendengarkan bunyi/suara sebagian besar berkembang sangat baik.

Pada kenyataanya jarang sekali orang tua/ pendidik yang secara khusus mengajarkan anak untuk mendengar. Sebagaimana Wulan Sari (2016) berpendapat bahwa ketrampilan untuk mendengar tidak pernah diajarkan atau kita pelajari dalam proses pembelajaran yang kita lakukan baik di sekolah formal maupun pendidikan informal lainnya. Namun demikian sebagai pendidik usaha meningkatkan kemampuan mendengar anak juga harus direncanakan dan dibingkai dalam program pembelajaran di pendidikan anak usia dini apakah melalui aktivitas bermain, karyawisata, eksperimen atau lainnya. 
Sebagaimana hasil penelitian yang menyimpulkan perlunya merangsang kemampuan auditori anak pada usia dini, karena peningkatan kemampuan auditori anak juga mendukung pengembangan lainnya seperti pengembangan bahasa, motorik, sosial dan emosional anak (Oktavia, 2012). Dengan kata lain auditori tidak usai pada kegiatan mendengarkan melainkan sebagai modal bagi anak agar dapat berbahasa dan bersosial, begitu juga dengan perkembangan emosional dan keterampilan motorik anak.

Menirukan nada, birama dan warna suara

Dari hasil pengolahan data hasil penelitian, didapatkan data pada indikator 2 yakni menirukan nada, birama dan warna suara sebagai berikut.

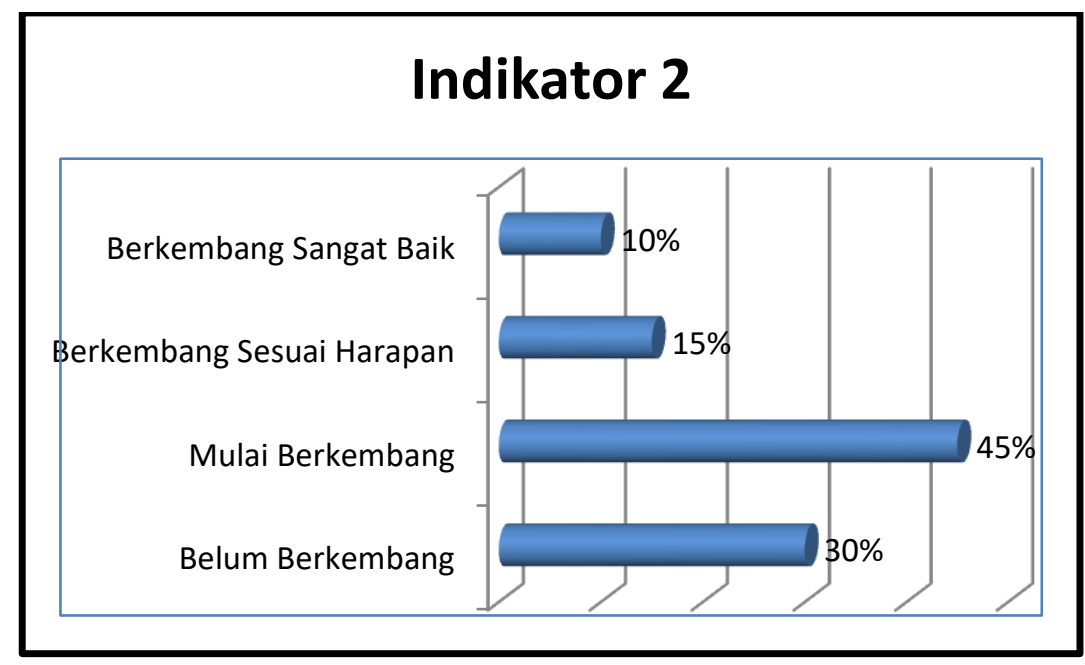

Diagram. 3 Data Indikator Kedua

Berdasarkan diagram diatas, anak yang dapat menirukan nada, birama, dan warna suara dengan sangat baik hanya $10 \%$ dan yang berkembang sesuai harapan $15 \%$ saja. Selanjutnya angka didominasi pada kategori mulai berkembang yakni berjumlah $45 \%$ dan $30 \%$ belum berkembang. Peran penting kemampuan auditori sangat terasa saat proses pembelajaran di kelas, karena sebagian besar waktu anak digunakan untuk mendengarkan apa yang guru sampaikan, apa yang teman-teman ceritakan, serta medi dan alat perminan yang disuguhkan. Bahkan dapat dikatakan keberhasilan aktivitas pembelajaran anak setiap harinya ditentukan dengan bagaimana kemampuan auditori anak. Setelah mendengarkan informasi, anak dituntut untuk mampu menirukan nada, birama dan warna suara yang didengar. Namun anak belum mendapat banyak kesempatan dalam berekspresi tentang suara yang diketahuinya. Sehingga perkembangan anak dalam menirukan nada, birama, dan warna suara masih belum memuaskan.

Suharso \& Renoningsih (2009) suara merupakan bunyi yang dikeluarkan dari mulut manusia seperti pada ketika bercakap-cakap, menyanyi, tertawa, menangis dan sebagainya; kerap pula dipakai dalam arti: bunyi binatang, alat perkakas, dan sebagainya; suatu yang dianggap sebagai perkataan untuk melahirkan pikiran, perasaan dan sebagainya. Senada dengan pernyataan tersebut Indrawati \& Tirono (2012) menyatakan bunyi suara merupakan getaran yang dihasilkan oleh getaran (bunyi) yang keluar dari mulut atau dihasilkan oleh makhluk hidup. Anak usia 4-5 tahun masih merupakan tahap praoperasional dalam perkembangan kognitif. Dimana pada tahap ini kemampuan skema kognitifnya masih sangat terbatas, peserta didik suka meniru perilaku orang lain khususnya orang tua dan guru yang pernah ia lihat ketika orang-orag tersebut merespons terhadap perilaku, keadaan, dan kejadian yang ada disekitarnya, sehingga iapun mulai mampu mengungkapkan dan mengexpresikan kalimat-kalimat pendek secara efektif (Azhari, 2017). Meskipun dalam tahapan properasional dengan keterbatasan skema kognitif, justru masa ini yang paling tepat untuk pengoptimalan pengembangan auditorinya, sehingga akan mendukung bidang 
perkembangan lainnya secara berkesinambungan. Oleh karena itu guru/pendidik bisa saja memanfaatkan moment ini, dimana anak gemar meniru orang disekelilingnya.

\section{Mengingat bunyi/suara}

Dari hasil pengolahan data hasil penelitian, didapatkan data pada indikator 3 yakni mengingat bunyi/suara sebagai berikut.

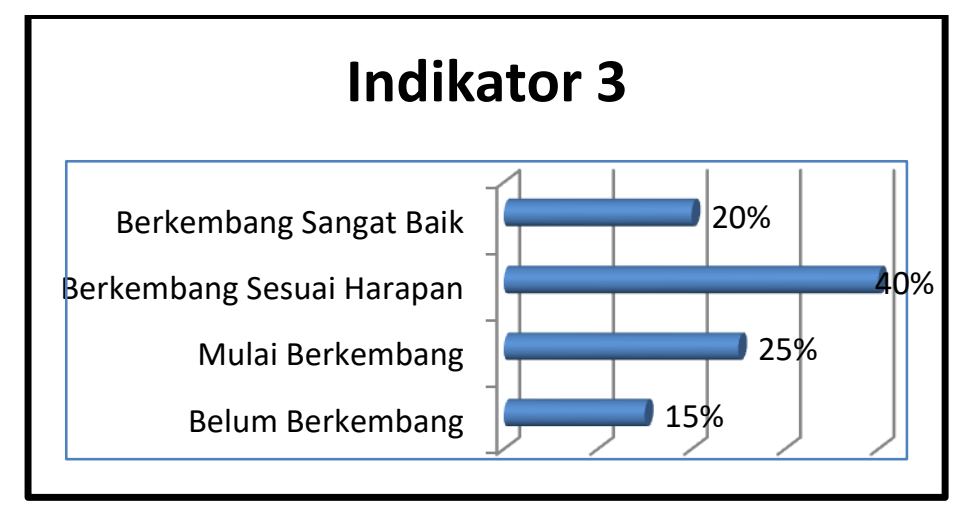

\section{Diagram. 4 Data Indikator Ketiga}

Dari diagram diatas dapat terlihat bahwa sebagian besar anak berkembang sesuai harapan dalam kemampuan mengingat bunyi/suara yakni dengan jumlah 40\%. Bahkan terdapat $20 \%$ anak yang telah berkembang sangat baik. Selanjutnya 25\% sudah mulai berkembang, dengan diikuti jumlah $15 \%$ pada kategori belum berkembang. Kemampuan mengingat pada anak usia dini tidak diperoleh secara automatis, melainkan dengan treatment dan latihan secara berkesinambungan. Kemampuan mengingat merupakan kemampuan kognitif paling dasar pada anak usia dini. Sebagaimana permasalahan yang sering terjadi pada anak usia dini dalam kegiatan pembelajaran, anak cenderung pasif. Sehingga ingatan anak juga tidak begitu optimal. Sebagaimana yang kita ketahui bahwa daya ingat anak banyak dipengaruhi oleh pengalamannya. Untuk itu pendidik dituntut untuk mampu memotivasi anak, dan berkreasi dalam strategi pembelajaran. Pendapat (Maemunah, 2017) bahwa kreatifitas guru dituntut agar proses pembelajaran dapat berlangsung menyenangkan dan variatif sehingga anak-anak tidak merasa bosan. Dengan tingginya ketertarikan anak pada kegiatan pembelajaran juga akan mendorong anak untuk lebih aktif dan partisipatif dalam bermain seraya belajar. Hal inilah yang diperlukan untuk merangsang daya ingat anak terhadap bunyi/suara yang telah didengar.

\section{Mengulangi kembali bunyi/suara yang telah didengar}

Dari hasil pengolahan data hasil penelitian, didapatkan data pada indikator 3 yakni mengulangi kembali bunyi/suara yang telah didengar sebagai berikut.

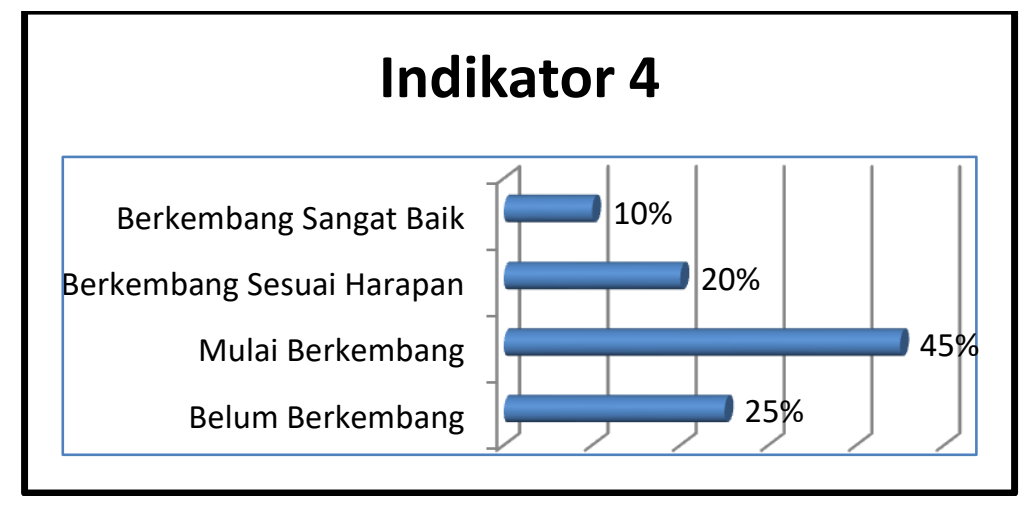

Diagram. 5 Data Indikator Keempat 
Pada diagram diatas dapat dilihat bahwa sebagian besar anak mulai berkembang dalam kemampuan mengulangi bunyi/suara yang telah didengar dengan persentase $45 \%$. Selanjutnya terdapat $10 \%$ anak yang telah berkembang sangat baik, dan $20 \%$ anak berkembang sesuai harapan. Sisanya berjumlah $25 \%$ anak masih belum berkembang. Hal ini dapat dipengaruhi banyak faktor, salah satunya anak tidak banyak mendapat pengalaman langsung dalam kemampuan mengulang. Namun demikian anak akan terus berproses dan bertahap. Sebagaimana (Rosalina, 2011) anak mengucapkan kata-kata secara fonetis pada awalnya pelan-pelan, penekanan diberikan pada tiap-tiap bunyi. Lambat laun masingmasing anak akan mampu memadukan bunyi-bunyi huruf secara individual bersama-sama dan mengucapkan kata secara keseluruhan. Sebagaimana penelitian yang dilakukan (Hermin \& Amanda, 2015) yang menyatakan bahwa jika lingkungan mampu memberikan banyak pengalaman kepada anak-anak dimungkinkan ruang lingkup kosakata anak akan lebih luas lagi. Anak diusia 4-5 tahun masih sangat dini yang membutuhkan bantuan dari orang dewasa baik guru atau orangtua.Dengan demikian sebagai pendidik di sekolah, dan orang tua di rumah harus cakap menyajikan aktivitas kreatif yang mampu meningkatkan kemampuan auditori anak usia dini.

Penelitian ini telah berhasil mengungkap kondisi perkembangan kognitif bidang auditori anak usia 4-5 tahun di Taman kanak-Kanak Islam Terpadu Taruna Islam Pekanbaru yang berada pada kategori cukup baik lengkap dengan hasil empat indikator. Dengan hasil penelitian ini peneliti, guru dan orangtua dapat mengidentifikasi kekuatan dan kelemahan masing-masing anak. Meskipun setiap anak mempunyai lintasan perkembangan dan lini masa pertumbuhan yang tidak persis sama, namun secara garis besar anak usia 4-5 tahun di Taman kanak-Kanak Islam Terpadu Taruna Islam Pekanbaru sudah berkembang sangat baik dalam mendengarkan bunyi/suara. Namun, perkembangan auditori yang dimaksud tidak hanya mendengarkan saja melainkan juga kemampuan anak dalam menirukan, mengingat, dan mengulang kembali bunyi/suara yang telah didengar, dalam hal ini hanya sebagian kecil saja anak yang berkembang sesuai harapan. Dengan kesadaran bahwa perkembangan auditori yang baik akan berpengaruh pada pengetahuan anak, kemampuan anak, serta pengalaman anak. Maka guru/pendidik perlu memberikan stimulasi khusus yang terfokus pada perkembangan auditori anak usia dini, hal ini dapat dilakukan melalui pengembangan strategi/metode pembelajaran, atau berbentuk permainan menggunakan media tradisional maupun memanfaatkan teknologi terkini yang berpengaruh baik untuk auditori anak usia dini. Sehingga dengan bantuan berupa stimulasi cepat dan tepat anak mampu berkembang sesuai harapan.

\section{KESIMPULAN}

Perkembangan kognitif bidang auditori anak usia 4-5 tahun di kelompok A1 pada Taman kanak-Kanak Islam Terpadu Taruna Islam Pekanbaru jika dirata-ratakan berada pada kategori cukup baik. Sehingga anak-anak kelompok A1 membutuhkan tindak lanjut berupa stimulasi tepat dan cepat yang dapat meningkatkan kemampuan auditori agar anak mampu memperoleh informasi dan dapat berinteraksi dengan lingkungan secara maksimal, selanjutnya anak dapat bertumbuh dan berkembang optimal dan maksimal sebagai penerus bangsa dimasa depan.

\section{UCAPAN TERIMA KASIH}

Peneliti mengucapkan terima kasih kepada seluruh pihak yang telah berkontribusi dan berpartisipasi dalam penelitian ini, sampai dengan selesainya penelitin dan terbitnya artikel ini. Semoga penelitian ini dapat bermanfaat bagi mahasiswa, guru, peneliti selanjutnya, dan seluruh pembaca. Serta dapat dijadikan landasan awal untuk pemberian stimulasi pada perkembangan kognitif khususnya pada bidang auditori anak usia dini. 


\section{DAFTAR PUSTAKA}

Aqib, Z. (2011). Pendidikan karakter : membangun perilaku positif anak bangsa. Yrama Widya.

Azhari. (2017). Peran guru dalam mengembangkan kemampuan Imajinasi terhadap keterampilan bercerita pada anak usia dini. Bunayya: Jurnal Pendidikan Anak, 1(2), 93-111. https://doi.org/https://doi.org/10.31004/obsesi.v1i2.22

Darna, D. (2018). Peningkatan Keterampilan Mendengarkan Cerita Anak Melalui Media Audio Visual Pada Siswa Kelas 1 SDN 020 Kualu Nenas Kecamatan Tambang Kabupaten Kampar. JURNAL PAJAR (Pendidikan Dan Pengajaran), 2(2), 194. https://doi.org/10.33578/ pjr.v2i2.5067

Fauziddin, M., \& Mufarizuddin, M. (2018). Useful of Clap Hand Games for Optimalize Cogtivite Aspects in Early Childhood Education. Jurnal Obsesi : Jurnal Pendidikan Anak Usia Dini, 2(2), 162. https://doi.org/10.31004/obsesi.v2i2.76

Hermin, R. A., \& Amanda, P. R. (2015). Pengaruh auditori verbal therapy tehadap kemampuan penguasaan kosa kata pada anak yang mengalami gangguan pendengaran. Pesona, Jurnal Psikologi Indonesia, (1), 77-86.

Indrawati, E., \& Tirono, M. (2012). Koefisien Penyerapan Bunyi Bahan Akustik Dari Pelepah Pisang Dengan Kerapatan Yang Berbeda. Jurnal Neutrino - Jurnal Fisika Dan Aplikasinya. https://doi.org/10.18860/neu.v0i0.1614

Inten, D. N., Permatasari, A. N., Guru, P., Anak, P., Dini, U., Bandung, U. I., Komunikasi, I., \& Bandung, U. I. (2019). Literasi Kesehatan pada Anak Usia Dini melalui Kegiatan Eating Clean. Jurnal Obsesi: Jurnal Pendidikan Anak Usia Dini, 3(2), 366-376. https://doi.org/10.31004/obsesi.v3i2.188

Khadijah. (2016). Pengembangan Kognitif Anak Usia Dini. Perdana Publishing.

Maemunah, S. (2017). Kreativitas Guru PAUD dalam Mengembangkan Media Pembelajaran Melalui Pemanfaatan Bahan Alam. Jurnal Ilmiah Pawiyatan, 22(3), 45-56.

Nasional, P. K. P. (2007). Kerangka dasar kurikulum pendidikan anak usia dini. Jakarta: Derpartemen Pendidikan Nasional.

Nasution, N., Yaswinda, Y., \& Maulana, I. (2019). Analisis Pembelajaran Berhitung melalui Media Prisma Pintar pada Anak Usia Dini. Jurnal Obsesi : Jurnal Pendidikan Anak Usia Dini, 4(1), 240. https://doi.org/10.31004/obsesi.v4i1.311

Novitasari, Y. (2018). Analisis Permasalahan" Perkembangan Kognitif Anak Usia Dini. PAUD Lectura: Jurnal Pendidikan Anak Usia Dini, 2(1), 82-90.

Oktavia, P. (2012). Peningkatan kemampuan auditori anak melaluipermainan media elektronik di taman kanak-kanak Aisyiyah Simpang IV Agam. Jurnal Pesona PAUD, 1((1)), 1-12.

Qudsyi, H. (2010). Optimalisasi Pendidikan Anak Usia Dini Melalui Pembelajaran yang Berbasis Perkembangan Otak. Buletin Psikologi, 18(2), 91-111.

Rosalina, A. (2011). Peningkatan Kemampuan Bahasa Anak Usia Dini Melalui Kegiatan Bermain. Psyco Idea, 1(1), 19-35.

Rusniah, R. (2017). Meningkatkan Perkembangan Bahasa Indonesia Anak Usia Dini Melalui Penggunaan Metode Bercerita Pada Kelompok A Di Tk Alahayati Neuhen Tahun Pelajaran 2015/2016. JURNAL EDUKASI: Jurnal Bimbingan Konseling, 3(1), 114. https://doi.org/10.22373/je.v3i1.1445

Suharso \& Renoningsih, A. (2009). Kamus Besar Bahasa Indonesia. Widya Karya.

Sukadi. (2008). Progresive Learning. Niaga Qolubun.

Sumantri. (2015). Strategi pembelajaran. Kharisma Putra Utama.

Syarifin, A. (2017). Percepatan Perkembangan Kognitif Anak: Analisis Terhadap Kemungkinan Dan Persoalannya. Al-Bahtsu, 2(1), 1-8.

Peraturan Menteri Pendidikan Dan Kebudayaan Republik Indonesia Nomor 137 tahun 2014 tentang Standar Nasional Pendidikan Anak Usia Dini, 13 (2014) (testimony of The Ministry of Education and Culture).

Wulan Sari, A. (2016). Pentingnya Ketrampilan Mendengar Dalam Menciptakan Komunikasi Yang Efektif. EduTech: Jurnal Ilmu Pendidikan Dan Ilmu Sosial, 2(1), 1-10. http://jurnal.umsu.ac.id/index.php/edutech/article/view/572

Yamin, H. M., \& Jamilah, S. S. (2010). Panduan Pendidikan Anak Usia Dini. GP Press.

Yuliani, N. (2006). Pembelajaran Pengembangan Kognitif. Universitas Terbuka. 